\title{
Influence of osmotic dehydration on bioactive compounds, antioxidant capacity, color and texture of fruits and vegetables: a review
}

\author{
Influência da desidratação osmótica sobre os compostos bioativos, \\ capacidade antioxidante, cor e textura de frutas e olerícolas: uma revisão
}

\author{
Ana Paula Miguel Landim ${ }^{I^{*}}$ \\ Maria Ivone Martins Jacintho Barbosa ${ }^{\mathrm{I}}$ José Lucena Barbosa Júnior $^{\mathrm{I}}$
}

- REVIEW -

ABSTRACT

Osmotic dehydration (OD) is a conservation technique applied to foodstuffs, which promotes partial reduction of water, extends their shelf life and reduces both post-harvest losses and changes in product characteristics. Currently, it has been given emphasis on trying to understand how the process affects the quality of processed vegetables, because process variables can interfere in their antioxidant capacity, color and texture. Moreover, the antioxidant capacity can be affected by chemical changes, leaching losses, reduced moisture and solid gain as well as the present bioactive in the profile of the performed analysis method. In color, the overall changes are caused by temperature increase, which can cause enzymatic and/or non-enzymatic browning, decomposition or entrainment of pigments present in the tissue. Conversely, the osmotic agent has a greater impact on texture, which causes changes in the sensory attributes such as gumminess, even crispness and flavor of the product. Although there is a large number of studies on the $O D$, the current scenario in terms of effect on the quality of osmodehydrated products are still incipient, especially in relation to antioxidant capacity. Despite the fact that there is a large number of studies on the $O D$, current efforts are focused on understanding the process effect on the product quality, notably in relation to antioxidant capacity. Thus, further studies on the internal changes in osmodehydrated foods are needed, since there is a variation of process factors, which may have an impact on the different tissues of the fruit and vegetable crops submitted to $O D$.

Key words: processing, quality, phytochemicals.

RESUMO

A desidratação osmótica (DO) é uma técnica de conservação de alimentos que promove a redução parcial de água, estende a validade comercial, diminui as perdas pós-colheita e as alterações nas características dos produtos. Atualmente, tem sido dada ênfase à busca do entendimento de como o processo afeta a qualidade dos vegetais desidratados, pois as variáveis do processo podem interferir em sua capacidade antioxidante, cor e textura. Além disso, a capacidade antioxidante pode ser afetada por transformações químicas, perdas por lixiviação, redução da umidade e ganho de sólidos, bem como pelo perfil dos compostos bioativos presentes e método de análise realizado. Quanto à cor, as alterações em geral são provocadas pelo aumento da temperatura, que pode ocasionar escurecimento enzimático elou não enzimático, decomposição ou carreamento dos pigmentos presentes no tecido. Por outro lado, o agente osmótico apresenta maior impacto na textura, provocando alterações nos atributos sensoriais como gomosidade, crocância e sabor do produto. Embora exista um grande número de trabalhos abordando a DO, os esforços atuais estão concentrados no entendimento sobre o efeito do processo sobre a qualidade dos produtos, sobretudo em relação à capacidade antioxidante. Dessa forma, há a necessidade de mais estudos sobre as alterações geradas pela DO nos alimentos, uma vez que há uma variação de fatores do processo, capaz de impactar de diversas formas os diferentes tecidos vegetais das frutas $e$ olerícolas submetidas à DO.

Palavras-chave: processamento, qualidade, fitoquímicos.

\section{INTRODUCTION}

Currently, it has been verified a growing demand for processed products of high sensory, functional and nutritional quality. Not only the ready-to-eat ones, but also the ingredients used in many areas of food industry, such as ice cream, dairy, cereals, bakery and confectionery products. Therefore, it has been verified an increase in the searching for processes which preserve the sensory and functional aspects of food (CARVALHO et al., 2006; CHANDRA \& KUMARI, 2015).

IDepartamento de Tecnologia de Alimentos, Universidade Federal Rural do Rio de Janeiro (UFRRJ), Rodovia BR 465, km 7, 23890-000, Seropédica, RJ, Brasil. E-mail: anapaula_landim@yahoo.com.br. "Corresponding author. 
In order to extend the shelf life of foods, conventional methods of dehydration have been largely applied. However, they usually are associated with reduction of nutritional, sensory and functional quality of the products undergoing these processes. Thus, partial moisture removal process like osmotic dehydration (OD), which reduces substantially these negative effects, has been shown to be a viable alternative in food processing over the past few years (YADAV \& SING, 2012; CHANDRA \& KUMARI, 2015).

Fruits (sliced or whole part) can be dehydrated by immersion in concentrated salts or sugar solutions. Thus, three simultaneous mass streams are generated: water loss from the fruit to the solution; migration of solutes from the solution to the fruit and loss of some soluble solids from fruit (such as sugar, minerals and many other water-soluble nutrients) to concentrated solution (RAOULT-WACK, 1994; TORREGIANI \& BERTOLO, 2001; YADAV \& SING, 2012; NIETO et al., 2013; CHANDRA \& KUMARI, 2015).

Since it does not apply high temperatures for water removal, the OD is more appropriated to some kinds of food than several other techniques, because OD promotes no drastic changes in some important properties, this ensures the preservation of natural compounds and the fruits properties (ANAND \& GENITHA, 2011; ALMEIDA et al., 2014; CHANDRA \& KUMARI, 2015).

Moreover, when it is used as pretreatment during the drying process, OD increases the quality of dehydrated fruits and vegetables (ATARES et al., 2011; MERCALI et al., 2011; ALMEIDA et al., 2014), because it minimizes the injury generated by further processes, which are often required to ensure the stability of the final product, once the OD promotes only a partial water removal (RASTOGI et al., 2002; ZHAO et al. 2013; MIMURA et al., 2014; CHANDRA \& KUMARI, 2015).

Nonetheless, the mass transfer rates between the solution and the food and the parameters related to the quality of fruits (i.e. the presence of phytochemicals with antioxidant capacity, the color and the texture) are influenced by the solute (type and concentration), agitation and temperature of the osmotic solution, proportion food/solute, shape and size of the food (OSORIO et al., 2007; RASTOGI et al., 2002; CASTRO-GIRÁLDEZ et al., 2011; NIETO et al., 2013; ALMEIDA et al., 2014).

In addition, there is a great interest to evaluate the quality by the nutritional point of view, as well as sensory characteristics, like color and texture variations, because they directly affect the acceptance of dehydrated fruits, since they can suffer physical and chemical changes during their processing (TALENS et al., 2002; OSORIO et al., 2007; CHONG et al., 2013; NIETO et al., 2013; ALMEIDA, et al., 2014).

Although the OD has been target of many studies over the years, most of the works evaluate the process kinetics in terms of water loss and solid gain and only a few studies report the process effect on the functional properties of osmodehydrated foods. However, it has been verified a great effort on the understanding of the effects related to the mass flows on the physical and chemical properties of the osmodehydrated fruits and vegetables.

Thus, the aim of this research was to provide an overview of the most recent studies, which evaluated the effects of osmotic dehydration on the main attributes related to sensory and functional quality of dehydrated fruits, mainly their antioxidant capacity, color and texture.

Quality parameters: Bioactive compounds and antioxidant capacity

The importance of the consumption of phytochemicals with antioxidant capacity is well known and, thus, studying the impact of osmotic processing on these substances has been required. The chemical compounds in fruits can suffer damages by different variables during the process. Besides, their content can be affected by chemical and biochemical transformations or by the leaching out from water flow. Conversely, the water reduction can generate an increase in the concentration of chemical compounds in the raw material, while the solid gain causes an opposite effect and promotes an apparent variation in concentration of chemical compounds in osmodehydrated fruits (BLANDA et al., 2009; ALMEIDA et al., 2014).

In table 1 , it is verified that high temperatures are related to negative effects on the antioxidant capacity of bananas (ALMEIDA et al., 2014), because the temperature increase causes a reduction on the membrane selectivity, which results in leaching of water soluble compounds (such as phenolics) to the osmotic solution (DEVIC et al., 2010). Moreover, high temperatures reduce viscosity of the osmotic solution and consequently the external resistance to the mass transfer that accelerates the process (BARBOSA JUNIOR et al., 2013). In addition, the OD process acts on degradation of some phenolic compounds and, thus, it reduces the antioxidant capacity (WOJDYŁO et al., 2007).

The osmotic agent applied in OD has direct influence on the retention of bioactive compounds 
Table 1 - Main effects of osmotic dehydration (OD) process on bioactive compounds and antioxidant capacity of foods.

\begin{tabular}{|c|c|}
\hline Product/Main observations & Authors \\
\hline \multicolumn{2}{|l|}{ Banana } \\
\hline $\begin{array}{l}\text { - Different temperatures were evaluated }\left(30,40 \text { and } 50^{\circ} \mathrm{C}\right) \text {. The highest retention of phenolics } \\
\text { compounds was observed at lower temperatures. }\end{array}$ & ALMEIDA et al. (2014) \\
\hline \multicolumn{2}{|l|}{ Strawberry } \\
\hline $\begin{array}{l}\text { - A combined HPP and OD processing presented a higher preservation in antioxidant capacity, } \\
\text { phenolics and vitamin C contents. }\end{array}$ & $\begin{array}{l}\text { NUÑEZ-MANCILLA et al. } \\
\text { (2013) }\end{array}$ \\
\hline \multicolumn{2}{|l|}{ - High pressure promotes higher preservative effect on phenolics content. } \\
\hline \multicolumn{2}{|l|}{ Blueberry } \\
\hline $\begin{array}{l}\text { - Sucrose solutions provided higher anthocyanins retention and glucose/fructose solutions } \\
\text { provided higher total phenolics content and antioxidant capacity. }\end{array}$ & GIOVANELLI et al. (2012) \\
\hline $\begin{array}{l}\text { Apple } \\
\text { - High temperature }\left(60^{\circ} \mathrm{C}\right) \text { reduces phenolics and vitamin } \mathrm{C} \text { contents. }\end{array}$ & DEVIC et al. (2010) \\
\hline \multicolumn{2}{|l|}{ Mushroom } \\
\hline $\begin{array}{l}\text { - OD at } 45^{\circ} \mathrm{C} \text { did not affect antioxidant capacity and total phenolics content (flavonoids and non- } \\
\text { flavonoids). }\end{array}$ & SINGLA et al. (2010) \\
\hline \multicolumn{2}{|l|}{ Cherry tomato } \\
\hline $\begin{array}{l}\text { - OD at } 50^{\circ} \mathrm{C} \text { promoted a reduction on lycopene and } \beta \text {-carotene contents. } \\
\text { - } 2 \% \text { of salt solutions reduced lycopene content. Conversely, sucrose solutions promoted } \\
\text { preservation of this phytochemical. }\end{array}$ & HEREDIA et al. (2009). \\
\hline
\end{tabular}

${ }^{*} \mathrm{HPP}=$ high pressure processing.

and their antioxidant capacity. The use of different solutes generates difference on the retention of these bioactive compounds, and consequently on antioxidant capacity (GIOVANELLI et al., 2012).

ALMEIDA et al. (2014) observed that the use of high concentrations of osmotic solution favored a higher retention of antioxidant capacity. The solute incorporation in the banana tissue had a protector effect because it generates a barrier to soluble solids leaching, mainly those which are responsible for antioxidant capacity, such as tannins and phenolic acids.

Water activity reduction and low $\mathrm{O}_{2}$ concentration reduce the phenolic compounds degradation rates. These effects arise from the solute penetration and the water loss by the vegetal tissue and the air absence in the food surroundings during the osmotic process, respectively. They reduce the action of enzymes, which could induce the loss of antioxidant capacity of these compounds (QUILES et al., 2005).

Moreover, different fruits have different characteristics regarding retention of phenolic compounds during OD. However, this difference can be correlated to the different phenolic profiles found in fruits, which present different behavior during the process (JACOB \& PALIYATH, 2012).

Even though the antioxidant capacity has not been directly evaluated in the processed samples, HEREDIA et al. (2009) reported that the osmotic process had no influence on the lycopene and e $\beta$-carotene content. However, under high temperatures $\left(50^{\circ} \mathrm{C}\right)$, the authors reported a decrease in the lycopene levels.

Conversely in certain processing conditions, some studies have reported an increase in carotenoids concentration, such as lycopene and $\beta$-carotene in osmodehydrated tomatoes. According to HEREDIA et al. (2009), this behavior was due to a hypothetical biosynthesis of those carotenoids as a response to the osmotic stress suffered by the fruit during the processing. However, TONON et al. (2007) proposed that OD promotes a disruption in the cell organelles, which could facilitate the further carotenoid extraction procedures and it could lead to an increase in the carotenoids levels.

Carotenoid biosynthesis occurs inside the plastids in the higher plants and it involves many 
reactions controlled by genetic transcription, which include the enzymatic production that is responsible for the pigment synthesis during the plant growth (OTHMAN et al., 2014; MARTINS et al., 2016). In addition, this biosynthesis needs numerous conditions to occur, which cannot be satisfied during the osmotic process. Thus, the increase in the carotenoids concentration under certain OD conditions needs more investigation.

The high pressure process (HPP) could efficiently improve the yield of flavonoids and other phenolics compounds in different types of vegetables and fruits. This effect is due to cell organelles disruption that improves the phenolic extraction and reduces the destruction flavonoids structure, which results in higher antioxidant capacity of the samples submitted to HPP (JING et al., 2016). Similar results were noticed for some authors who studied grape (CORRALES et al., 2008), watermelon (OMS-OLIU et al., 2009) and strawberry (NUÑEZ-MANCILLA et al., 2011, 2013) residues.

SINGLA et al. (2010) evaluated the effect of OD as pre-treatment to vacuum drying in mushrooms and verified that OD reduced the drying time, which favors a higher retention of the nutritional substances that are usually instable, when it was exposed to a high temperature for a long time.

Conversely, NOWICKA et al. (2014) verified that OD presented a negative effect on total phenolic content and antioxidant capacity in sour cherry fruits. However, the OD was an important pre-treatment in dehydration, since it reduced the water activity in over $50 \%$ and, in this case, on following treatments of convective drying and vacuum microwave drying, the time, the temperature and the microwave power required to complete the dehydration were lower.

Quality parameters: color

Color changes during the osmotic dehydration can be very significant. Therefore, color parameters are evaluated in the fruits before and after the processing (OSORIO et al., 2007). These alterations can occur because of the degradation pigment losses in fruits; browning development during the processing; or increase in pigments concentration caused by water loss, which can increase simultaneously the refractive index of food liquid phase and it impacts mainly in color attributes, such as luminosity and Chroma (TALENS et al., 2002).

Color changes play a crucial role in the food products acceptance and it is related to the pigments alterations in the foods during processing, such as enzymatic or non-enzymatic browning. The use of low temperatures associated with the protector effect that sugar has in some pigments can minimize these alterations during OD process (CHIRALT \& TALENS, 2005).

High temperatures cause a more intense browning on osmodehydrated fruits. Chemical reactions, which form browning pigments, are favored by water activity reduction that occurs during the osmotic process. Moreover, high temperatures can favor the browning by chemical and enzymatic reactions that lead to oxidation of phenolic compounds and Maillard reaction, which involves presence of reducing sugar and amino acids (ATARES et al., 2011; ALMEIDA et al., 2014).

Both temperature and solute concentration are linked to the color changes, which are verified in dehydrated products (Table 2). HEREDIA et al. (2009) reported that the color alteration in dehydrated cherry tomato was more pronounced when the process occurred under high temperature, especially when sucrose was used. This alteration was due to the higher water loss and, thus, a higher lycopene concentration in the tissue. This change indicates that there was no pigment degradation, which results in higher nutritional quality products.

However, the process parameters can distinctly affect the color of different fruits, since these factors depend on the vegetal tissue characteristics, pigments and physicochemical properties, such as tortuosity, permeability, solubility, water activity, etc. ATARES et al. (2011) observed no average differences between the color of fresh and osmodehydrated bananas in all studied conditions of temperature and osmotic solution concentration, which means a higher product color quality that has direct influence on the dehydrated fruits acceptance by consumers.

The application of high concentrated solutions favors higher water loss and it generates a concentration effect on the pigments in the fruit tissue, which lead to alterations in the instrumental color parameters. However, these alterations are lower than the changes caused by other dehydration processes (SILVA et al., 2014). The use of osmotic dehydration as pre-treatment allows the obtainment of dehydrated fruits with more natural color appearance. Many studies could observe a protective effect on the color of fruits and vegetables submitted to osmotic pre-treatment, such as in air-dried carrot (KOWALSKI \& MIERZWA, 2011), in lyophilized strawberry (GARCIA-NOGUERA et al., 2012), in frozen mango (ZHAO et al., 2013) 
Table 2 - Main effects of osmotic dehydration (OD) on color attributes of foods.

\begin{tabular}{|c|c|}
\hline Product/Main observations & Authors \\
\hline $\begin{array}{l}\text { Banana } \\
\text { - OD did not affect the color parameters }\left(a^{*}, b^{*} \text { and } \Delta E\right) \text {, but temperature presented effect on } L^{*} \text { value. }\end{array}$ & ALMEIDA et al. (2014) \\
\hline $\begin{array}{l}\text { Mango } \\
\text { - Glucose showed more intense effect on color parameters than sucrose and maltose. }\end{array}$ & ZHAO et al. (2014) \\
\hline $\begin{array}{l}\text { Pineapple } \\
\text { - Higher concentration sucrose promoted an increase on } C^{*} \text { values of osmo-dehydrated pineapples. }\end{array}$ & SILVA et al. (2014) \\
\hline $\begin{array}{l}\text { Banana and beet } \\
\text { - Higher times and solution concentration promoted lower color changes on pre-treated (OD) dried } \\
\text { bananas and beet. }\end{array}$ & KOWALSKI et al. (2013) \\
\hline $\begin{array}{l}\text { Cherry tomato } \\
\text { - The } \mathrm{L}^{*} \text { values were reduced. } \\
\text { - High temperature favored the increase on } \mathrm{a}^{*} \text { and } \mathrm{b}^{*} \text { values, especially using sucrose as osmotic agent. }\end{array}$ & HEREDIA et al. (2009). \\
\hline $\begin{array}{l}\text { Strawberry } \\
\text { - An reduction on Hue was verified after long immersion times. } \\
\text { - The impregnated sucrose in the tissue performed an important role on the changes of } \mathrm{L}^{*} \text { and } \mathrm{C}^{*} \text { values. }\end{array}$ & $\begin{array}{l}\text { GARCIA-NOGUERA et al. } \\
(2012) \text {. }\end{array}$ \\
\hline
\end{tabular}

and in mango chips (ZOU et al., 2013). According to KOWALSKI et al. (2013), the use of OD as pre-treatment in banana and beet reduced the time required for drying, which leads to a lower color degradation in the dehydrated products.

Quality parameters: texture

Texture is one of the main qualitative parameters and it is related to the rheological and structural food properties, which can be evaluated by different mechanical parameters, such as firmness, adhesiveness, cohesiveness, gumminess and viscosity (NIETO et al., 2013).

Mechanical properties of vegetal tissues are influenced by cellular swelling, force of connection between cells (middle lamella), cell wall resistance to compression and traction forces, and other factors like size, shape, temperature and strain rate of the sample (NIETO et al., 2013).

Some studies about the effect of osmotic treatment on the texture of fruits and vegetables are presented in table 3. According to ZHAO et al. (2014), the incorporation of sugar and calcium chloride during OD contributed to the firmness increase in frozen mangoes. The sugar promoted increase in cell integrity and the calcium chloride interacted with the cell structure of the food matrix. OLATIDOYE et al. (2010) observed the same effect during the thawing of the osmotically pre-treated tomatoes, which presented an increase in firmness caused by solute incorporation in the fruit structure.

Loss of firmness is related to pectin and insoluble protopectin degradation, since they are responsible for the structural rigidity of the fruit. Action of pectinase enzymes, mainly the polygalacturonase and polymethylesterase in ripe fruits, causes pectic substances solubilization. Reduction of respiration rate in fruits reduces the enzyme activity, which results in a lower effect on the food texture (FERRARI et al., 2013).

Presence of calcium lactate also causes a protector effect on the texture, since these ions act on vegetal tissue in which they could form complexes with caboxyl groups of pectin and, thus, produce an increase in the firmness. This effect reduces the damage caused to cell wall structure by the dehydration process. Moreover, the use of these salts can increase the water loss rates, which reduces the water activity of the processed products (SILVA et al., 2013; SILVA et al., 2014; ZHAO et al., 2014).

According to TORRES et al. (2006), the higher concentrations of calcium lactate, higher the food processed firmness. Conversely, at very high concentrations an opposite effect could be verified, in which the rupture of the cell membranes promoted by pectin dissolution and consequently causing a considerable reduction in the tissue firmness (SILVA et al., 2014). 
Table 3 - Main effects of osmotic dehydration (OD) on texture of foods.

\begin{tabular}{|c|c|}
\hline Product/Main observations & Authors \\
\hline $\begin{array}{l}\text { Manga } \\
\text { - An increase on firmness, independently if the slow- or quick-freezing step were utilized, after OD. }\end{array}$ & ZHAO et al. (2014) \\
\hline $\begin{array}{l}\text { Melão } \\
\text { - Pre-treated samples by OD and associated to edible coating did not differ significantly from fresh fruits. }\end{array}$ & FERRARI et al. (2013) \\
\hline $\begin{array}{l}\text { Mango } \\
\text { - OD reduced the hardness of samples. However, the use of calcium in the solution promoted the opposite } \\
\text { effect. } \\
\text { - Higher solute concentrations provided firmer and more resistant to deformation samples, and the presence } \\
\text { of calcium lactate favored this effect. }\end{array}$ & TORRES et al. (2006) \\
\hline $\begin{array}{l}\text { Pineapple } \\
\text { - Lower calcium lactate concentrations promoted an increase on firmness in relation to higher ones. }\end{array}$ & SILVA et al. (2014) \\
\hline $\begin{array}{l}\text { Apple } \\
\text { - Higher temperatures caused more impact on texture, resulting in considerable loss of firmness in the } \\
\text { tissue. }\end{array}$ & $\begin{array}{l}\text { MAVROUDIS et al. } \\
(2012) \text {. }\end{array}$ \\
\hline $\begin{array}{l}\text { Grapefruit } \\
\text { - An increase on the mechanical parameters (strain-stress curve parameters) was observed. } \\
\text { - No differences were observed in the texture of the samples osmo-dehydrated with or without calcium } \\
\text { lactate. }\end{array}$ & MORAGA et al. (2009). \\
\hline
\end{tabular}

Efficiency of calcium on the firmness improvement is influenced by the fruit tissue structure. MORAGA et al. (2009) have reported different mechanical properties in the tissue of osmodehydrated toranja, mainly when compared to other fruits, which have parenchymatic tissue. The toranja tissue is formed by segments of long cells filled with juice and part of it is extracted during the cutting process of samples that influenced the mechanical behavior of this fruit.

According to MAVROUDIS et al. (2012), the temperature plays an important role on the firmness of osmodehydrated apples. At higher temperatures, it is verified a reduction on the wall turgor (via water loss and solid gain by cells) and an increase on temperatureinduced tissue softening. These effects occur simultaneously, are temperature-induced by different ways and responsible for the overall effect of this factor on the texture.

Different variations in process parameters (temperature, solution and fruit) result in different mass transfer kinetics during the OD and affect the composition of vegetal tissue in distinct ways. These effects promoted unequal physico-chemical changes in osmodehydrated products (JACOB \& PALIYATH, 2012; NIETO et al., 2013).

\section{CONCLUSION}

Osmotic dehydration plays an important role in the preservation of the sensory and functional attributes of processed food, and also reduces the thermal and oxidative injuries, when used as pre-treatment to other preservation technics. However, despite of being a largely studied process, studies aimed to understand the effect of this process on the antioxidant capacity of osmodehydrated products are lacking. Thus, more studies by this perspective are required. Moreover, the different variables involved in the process act in distinct ways over color and texture characteristics of the different vegetal tissues submitted to OD.

Studies which optimize the process regarding the conservation of bioactive compounds, their antioxidant capacity and the maintenance of color and texture, can enlarge industrial application of this technique and provide high sensorial and functional quality products.

\section{REFERENCES}

ALMEIDA, J.A.R. et al. Effect of temperature and sucrose concentration on the retention of polyphenol compounds and antioxidant activity of osmotically dehydrated bananas. Journal of

Ciência Rural, v.46, n.10, out, 2016. 
Food Processing and Preservation, v.38, p.1-9, 2014. Available from: $\quad<$ http://onlinelibrary.wiley.com/doi/10.1111/jfpp.12321/ pdf $>$. Accessed: Dec. 24, 2014. doi: 10.1111/jfpp.12321.

ANAND, P.; GENITHA T.R. Physico chemical and sensory qualities of osmo dehydrated banana (Musa paradisiaca). Progressive Agriculture, v.1, p.330-336, 2011.

ATARES, L. et al. Process conditions effect on the quality of banana osmotically. Journal of Food Engineering, v.103, p.401-408, 2011. Available from: <http:/www.sciencedirect. com/science/article/pii/S0260877410005479\#>. Accessed: Jan. 08, 2015. doi: 10.1016/j.jfoodeng.2010.11.010.

BARBOSA JÚNIOR, J.L. et al. Mass transfer kinetics and mathematical modelling of the osmotic dehydration of orangefleshed honeydew melon in corn syrup and sucrose solutions. International Journal of Food Science and Technology, v.48, p.2463-2473, 2013. Available from: $<$ http://onlinelibrary.wiley. com/doi/10.1111/ijfs.12237/pdf>. Accessed: Dec. 22, 2014. doi: $10.1111 / \mathrm{ijfs} .12237$.

BLANDA, G. et al. Osmotic dehydrofreezing of strawberries: Polyphenolic content, volatile profileand consumer acceptance. Food Science and Technology, v.42, p.30-36, 2009. Available from: <http://65.54.113.26/Publication/41282657>. Accessed: Jan. 02, 2015. doi: 10.1016/j.1wt.2008.07.002.

CARVALHO, P. et al. Hortaliças como alimentos funcionais. Revista Horticultura Brasileira, v.24, p.397-404, 2006. Available from: <http://www.scielo.br/pdf/hb/v24n4/01. pdf $>$. Accessed: Feb. 03, 2015. doi: 10.1590/S010205362006000400001

CASTRO-GIRÁLDEZ, $M$. et al. Influence of process conditions on mechanical properties of osmotically dehydrated mango. Journal of Food Engineering, v.74, p.240-246, 2011 Available from: <http://www.sciencedirect.com/science/article/ pii/S0260877410006059>. Acessed: Feb. 03, 2015. doi: 10.1016/j.jfoodeng.2010.10.034.

CHANDRA, S.; KUMARI, D. Document recent development in osmotic dehydration of fruit and vegetables: a review. Critical Reviews in Food Science and Nutrition, v.55, p.552-561, 2015.

CHIRALT, A.; TALENS P. Physical and chemical changes induced by osmotic dehydration in plant tissues. Journal of Food Engineering, v.67, p.167-177, 2005. Available from: <http:// www.sciencedirect.com/science/article/pii/S0260877404003322>. Accessed: Dec. 17, 2014. doi: 10.1016/j.jfoodeng.2004.05.055.

CHONG, C.H. et al. Colour, phenolic content and antioxidant capacity of some fruits dehydrated by a combination of different methods. Food Chemistry, v.141, p.3889-3896, 2013. Available from: <http://www.sciencedirect.com/science/ article/pii/S030881461300819>. Accessed: Jan. 03, 2015. doi: 10.1016/j.foodchem.2013.06.042.

CORRALES, M. et al. Extraction of anthocyanins from grape by-products assisted by ultrasonics, high hydrostatic pressure or pulsed electric fields: a comparison. Innovative Food Science \& Emerging Technologies, v.9, p.85-91, 2008. Available from: $<$ http://www.sciencedirect.com/science/article/ pii/S1466856407000756>. Accessed: Jan. 15, 2015. doi: 10.1016/j.ifset.2007.06.002.
DEVIC, E. et al. Effect of temperature and cultivar on polyphenol retention and mass transfer during osmotic dehydration of apples. Journal Agricultural and Food Chemistry, v.58, p.606-614, 2010. Available from: <http:// pubs.acs.org/doi/ipdf/10.1021/jf903006g>. Accessed in: Jan. 15, 2015. doi: $10.1021 / \mathrm{jf} 903006 \mathrm{~g}$.

FERRARI, C. C. et al. Effect of osmotic dehydration and pectin edible coating on quality and shelf life of fresh-cut melon. Food and Bioprocess Technology, v.4, p.1-12, 2013. Available from: <http://download.springer.com/static/pdf/567/art\%253A 101007\%252Fs11947011-07046.pdf>. Accessed: Jan. 01, 2015. doi: $10.1007 / \mathrm{s} 11947-011-0704-6$.

GARCIA-NOGUERA, J. et al. Effect of ultrasonic and osmotic dehydration pre-treatments on the colour of freeze dried strawberries. Journal of Food Science and Technology, v.51, p.1-6, 2012. Available from: <http://link.springer.com/ article/10.1007\%2Fs13197-012-0724-x\#page-1>. Accessed: Mar. 03, 2015. doi: 10.1007/s13197-012-0724-x.

GIOVANELLI, G. et al. Effects of blanching pre-treatment and sugar composition of the osmotic solution on physicochemical, morphological and antioxidant characteristics of osmodehydrated blueberries (Vaccinium corymbosum L.). Food Research International, v.49, p.263-271, 2012. Available from: <http://www.sciencedirect.com/science/article/ pii/S0963996912003249>. Accessed: Jan. 08, 2015. doi: 10.1016/j.foodres.2012.08.015.

HEREDIA, A. et al. Influence of process variables on colour changes, carotenoids retention and cellular tissue alteration of cherry tomato during osmotic dehydration. Journal of Food Composition and Analysis, v.22, p.285-294, 2009. Available from: <http://www.sciencedirect.com/science/ article/pii/S0889157509000805>. Accessed: Mar. 04, 2015. doi: $10.1016 /$ j.jfca.2008.11.018.

JACOB, J.K.; PALIYATH, G. Infusion of fruits with nutraceuticals and health regulatory components for enhanced functionality. Food Research International, v.45, p.93-102, 2012. Available from: $<\mathrm{http}: / / \mathrm{www} . s c i e n c e d i r e c t . c o m /$ science/ article/pii/S096399691100593X?np=y>. Accessed: Jan. 13, 2015. doi: 10.1016/j.foodres.2011.10.017

JING. J. et al. Dynamic high pressure microfluidizationassisted extraction and bioactivities of Cyperus esculentus (C. esculentus L.) leaves flavonoids. Food Chemistry, v.192, p.319-327, 2016. Available from: <http://www.sciencedirect. com/science/article/pii/S0308814615009899>. Accessed: Feb. 13, 2016. doi: 10.1016/j.foodchem.2015.06.097.

KOWALSKI, S.J.; MIERZWA, D. Influence of preliminary osmotic dehydration on drying kineticsand final quality of carrot (Daucus carota L.). Chemical and Process Engineering, v.32, p.185-194, 2011. Available from: <http://processengineering.net/chpe/ download/02Influenceofpreliminaryosmoticdehydrationon. pdf $>$. Accessed: Jan. 02, 2015. doi: 10.2478/v10176-011-0014-6.

KOWALSKI, S.J et al. Quality aspects of fruit and vegetables dried convectively with osmotic pretreatment. Chemical and Process Engineering, v.34, p.51-62, 2013. Available from: $<$ http://yadda.icm.edu.pl/baztech/element/bwmeta1.element. baztech-61d1b53f-29e8-4d68-a4ca-386129f435bb>. Accessed: Jan. 02, 2015. doi: 10.2478/cpe-2013-0005. 
MARTINS, G.F. et al. The ripening influence of two papaya cultivars on carotenoid biosynthesis and radical scavenging capacity. Food Research International, v.81, p.197-202, 2016. Available from: $<$ http://linkinghub.elsevier.com/retrieve/ pii/S0963996915302660>. Accessed: Mar. 10, 2016. doi: 10.1016/j.foodres.2015.11.027.

MAVROUDIS, N.E et al. Osmotic processing: effects of osmotic medium composition on the kinetics and texture of apple tissue. Food Research International, v.48, p.839-847, 2012. Available from: $<\mathrm{http}: / / \mathrm{www}$. sciencedirect.com/science/ article/pii/S0963996912002384>. Accessed: Jan. 02, 2015. doi: 10.1016/j.foodres.20 12.06.034.

MERCALI, D.G. et al. Evaluation of water, sucrose and $\mathrm{NaCl}$ effective diffusivities during osmotic dehydration of banana (Musa sapientum, shum). LWT - Food Science and Technology, v.44, p.82-91, 2011. Available from: $<$ http://www. sciencedirect.com/science/article/pii/S002364381000229X $>$. Accessed: Jan. 14, 2015. doi: 10.1016/j.foodres.2011.10. 017.

MIMURA, H.J. et al. Pré-tratamentos na secagem e reidratação de champignon em fatias. Ciência Rural, v.44, p.717-722, 2014. Available from: <http://www.scielo.br/pdf/cr/v44n4/ a12014cr2013-0785.pdf>. Accessed: Jan. 03, 2015. doi: 10.1590/S0103-84782014000400024.

MORAGA, M.J. et al. Effect of vacuum impregnation with calcium lactate on the osmotic dehydration kinetics and quality of osmodehydrated grapefruit. Journal of Food Engineering, v.90, p.372-379, 2009. Available from: <http://www. sciencedirect.com/science/article/pii/S0260877408003427>. Accessed: Mar. 03, 2015. doi: 10.1016/j.jfoodeng.2008.0 7.007.

NIETO A.B. et al. Osmotic dehydration of apple: Influence of sugar and water activity on tissue structure, rheological properties and water mobility. Journal of Food Engineering, v.119, p.104-114, 2013. Available from: <http://www. sciencedirect.com/science/article/pii/S0260877413002148>. Accessed: Dec. 06, 2014. doi: 10.1016/j.jfoodeng.2013.04.032.

NOWICKA, P. et al. Influence of osmodehydration pretreatment and combined drying method on the bioactive potential of sour cherry fruits. Food and Bioprocess Technology, v.8, p.824-836, 2014. Available from: <http://link.springer.com/ article/10.1007\%2Fs11947-014-1447-y>. Accessed: Mar. 03, 2015. doi: 10.1007/s11947-014-1447-y.

NUÑEZ-MANCILLA, Y. et al. Osmotic dehydration under high hydrostatic pressure: effects on antioxidante activity, total phenolics compounds, vitamin $\mathrm{C}$ and colour of strawberry (Fragaria vesca). LWT - Food Science and Technology, v.52, p.151-156, 2013. Available from: <http://www.sciencedirect. com/science/article/pii/S0023643812001053>. Accessed: Jan. 03, 2015. doi: 10.1016/j.1wt.2012.02.027.

OLATIDOYE, O.P. et al. Effect of osmodehydrofreezing on the quality attributes of frozen tomato. Electronic Journal of Environmental, Agricultural and Food Chemistry, v.9, p.780-789, 2010.

OMS-OLIU, G. et al. Effect of high-intensity pulsed electric field processing conditions on lycopene, vitamin $\mathrm{C}$ and antioxidant capacity of watermelon juice. Food Chemistry, v.115, p.13121319, 2009. Available from: <http://www.sciencedirect.com/ science/article/pii/S0308814609000909>. Accessed: Jan. 20, 2015. doi: 10.1016/j.foodchem.2009.01.049.
OSORIO, C. et al. Colour and flavour changes during osmotic dehydration of fruits. Innovative Food Science and Emerging Technologies, v.8, p.353-359, 2007. Available from: <http://www.sciencedirect.com/science/ article/pii/S1466856407000379>. Accessed: Nov. 30, 2014. doi:10.1016/j.ifset.2007.03.009.

OTHMAN, R. et al. Carotenoid biosynthesis regulatory mechanisms in plants. Journal of Oleo Science, v.63, n.8, p.753-760, 2014. Available from: <http://www.ncbi.nlm. nih.gov/pubmed/25017864>. Accessed: Mar. 10, 2016. doi: $10.5650 /$ jos.ess 13183 .

QUILES, A. et al. Polyphenoloxidase (PPO) activity and osmotic dehydration in Granny Smith apple. Journal of the Science of Food and Agriculture, v.85, p.1017-1020, 2005. Available from: <http://onlinelibrary.wiley.com/doi/10.1002/jsfa.2062/ pdf $>$. Accessed: Feb. 03, 2015. doi: 10.1002/jsfa.2062.

RAOULT-WACK, A.L. Recent advances in the osmotic dehydration of foods. Trends in Food Science and Technology, v.5, p.255-260, 1994

RASTOGI, N.K. et al. Recent developments in osmotic dehydration: methods to enhance mass transfer. Trends in Food Science and Technology, v.13, p.48-59, 2002. Available from: <http://www.sciencedirect.com/science/ article/pii/S0924224402000328>. Accessed: Nov. 26, 2014. doi:10.1016/S0924-2244(02)00032-8.

SILVA, K.S. et al. Effect of calcium on the osmotic dehydration kinetics and quality of pineapple. Journal of Food Engineering, v.134, p.37-44, 2014. Available from: <http:// dx.doi.org/10.1016/j.jfoodeng.2014.02.020>. Accessed: Jan. 01, 2015. doi: 10.1016/j.jfoodeng.2014.02.020.

SILVA, K.S. et al. Osmotic dehydration of pineapple with impregnation of sucrose, calcium and ascorbic acid. Food and Bioprocess Technology, v.7, p.385-397, 2013. Available from: <http://link.springer.com/article/10.1007/ s11947-013-1049-0\#page-1>. Accessed: Jan. 01, 2015. doi: $10.1007 / \mathrm{s} 11947-013-1049-0$.

SINGLA, R. et al. Antioxidant activities and polyphenolic properties of raw and osmotically dehydrated dried mushroom (Agaricus bisporous) snack food. International Journal of Food Properties, v.13, p.1290-1299, 2010. Available from: <http:// www.tandfonline.com/doi/abs/10.1080/10942910903061851?jour nalCode=ljfp20\#.VKlvoivF_oE $>$. Accessed: Jan. 02, 2015. doi: $10.1080 / 109429109030618 \overline{5} 1$

TALENS, P. et al. Changes in optical and mechanical properties during osmodehydro- freezing of kiwi fruit. Innovative Food Science and Emerging Technologies, v.3, p.191-199, 2002.

TONON, R.V. et al. Osmotic dehydration of tomato in ternary solutions: influence of process variables on mass transfer kinetics and an evaluation of the retention of carotenoids. Journal of Food Engineering, v.82, p.509-517, 2007. Available from: <http:// www.sciencedirect.com/science/article/pii/S0260877407001756>. Accessed: Mar. 10, 2016. doi: 10.1016/j.jfoodeng.2007.03.008.

TORREGIANI, D.; BERTOLO, G. Osmotic pre-treatments in fruit processing: chemical, physical and structural effects. Journal of Food Engineering, v.49, p.247-253, 2001. Available from: <http:/www.sciencedirect.com/science/article/ 
pii/S0260877400002107>. Accessed: Nov. 25, 2014. doi: 10.1016/S0260-8774(00)00210-7.

TORRES, J.D. et al. Influence of process conditions on mechanical properties of osmotically dehydrated mango. Journal of Food Engineering, v.74, p.240-246, 2006. Available from: <http://www.sciencedirect.com/science/article/ pii/S026087740500149 4\#>. Accessed: Dec. 31, 2005. doi: 10.1016/j.jfoodeng.2005.03.017.

WOJDYŁO, A. et al. Influence of temperature and time of apple drying on phenolic compounds content and their antioxidant activity. Polish Journal of Food and Nutrition Sciences, v.57, p.601-605, 2007.

YADAV, A.S.; SING, S.V. Osmotic dehydration of fruits and vegetables: a review. Journal of Food Science and Technology, v.51, p.1654-1673, 2012. Available from: <http://link.springer. com/article/10.1007\%2Fs13197-012-0659-2>. Accessed: Jan. 15, 2015. doi: 10.1007/s13197-012-0659-2.

ZHAO, J.H. et al. Osmotic dehydration pretreatment for improving the quality attributes of frozen mango: effects of different osmotic solutes and concentrations on the samples. International Journal of Food Science and Technology, v.49, p.960-968, 2014. Available from: <http://www.tandfonline.com/ doi/abs/10.1080/10942910701671349\#.VJgcr14AA>. Accessed: Dec. 16, 2014. doi: 1111/ijfs.12388.

ZOU, K. et al. Effect of osmotic pretreatment on quality of mango chips by explosion puffing drying. LWT - Food Science and Technology, v.51, p.253-259, 2013. Available from: $<$ http:// www.sciencedirect.com/science/article/pii/S0023643812004537>. Accessed: Dec. 17, 2014. doi:10.1016/j.1wt.2012.11.005. 